\title{
FIBRE MORPHOLOGICAL VARIATIONS OF SOME NIGERIAN GUINEA SAVANNAH TIMBER SPECIES
}

\author{
Nusirat Aderinsola Sadiku ${ }^{1, \AA}$, Kafilat Adejoke Abdukareem ${ }^{1}$
}

\begin{abstract}
Fibre morphology of some Nigerian tropical timber species were evaluated to determine their potentials as suitable source of raw material for pulp and paper making. The fibre dimension of the species showed that Syzygium guineense had the longest fibre length $(2,0 \mathrm{~mm})$ followed by Anogeissus leiocarpa $(1,75 \mathrm{~mm})$ while Albizia zygia had the shortest fibre length of 1,05 mm. Irvingia gabonensis had the largest fibre diameter while Vernonia colorata had the smallest. Vitellaria paradoxa had the widest lumen of 8,87 $\mu \mathrm{m}$ while Irvingia gabonensis had the smallest lumen and thickest $(6,87 \mu \mathrm{m})$ cell wall while Vernonia colorata had the thinnest $(4,40 \mu \mathrm{m})$. Albizia zygia had the most slender fibres while Vitellaria paradoxa had the most rigid fibres. All the species had narrow fibre lumens and the cell walls were thick, which may have given poor results to the pulp made from them. The results of the analysis of variance showed that there was high significant variation in all the fibre dimensions and the derived values of the species. Duncan Multiple Range test showed that no statistical difference existed in the fibre length of Isoberlina doka, Khaya ivorensis and Albizia zygia. However, Vernonia colorata, Irvingia gabonensis and Vitellaria paradoxa had similar fibre length as well as Afzelia africana and Lannea welwitchii. All the species passed the Runkel Ratio $<1$ acceptable values for paper making fibre except Vitellaria paradoxa and Anogeissus leiocarpa with Runkel Ratio value of 1,38 and 1,03. Syzygium guineense and Irvingia gabonensis passed flexibility coefficient $>0,55$ for an acceptable value for paper making. All the fibres were elastic except Vitellaria paradoxa and Anogeissus leiocarpa.
\end{abstract}

Keywords: Derived values, fibre dimensions, hardwood, pulp and paper making, runkel ratio.

\section{INTRODUCTION}

Differences exist among different species of wood, their genera and families. Variations occur within individual trees from the pith outwards, from base to top along the stem of the tree (Jaiyeola et al. 2009) and among individuals of the same species. This variability influences utilization of wood for specific end uses. Microscopic features of wood influence wood properties, processing and the final end products of wood. Cell size, proportion and arrangement of the various types of elements and tissues determines the grains of wood, its feel to the touch, and the beautiful figures appearing on most species. In the same vain, the morphology of the fibres are important indices in evaluating the suitability of fibre for pulp and papermaking. A number of species have been studied by various researchers for pulp and paper making. Steculia setigera and Steculia oblonga were studied by Ogunwusi (2002) and Osadare (1997). These species were termed suitable for papermaking based on their fibre lengths of 2,41 $\mathrm{mm}$ and 2,07 mm respectively. Ogunkunle and Oladele (2008) recommended Twelve species of Ficus, while Leucaena leucocephala (Oluwadare et al. 2007), Vitex Doniana (Ogunjobi et al. 2014) were reported to be suitable sources of hardwood fibre for paper making.

The paper making characteristics of any given pulp is a function of the chemical and fibre properties of the plant. Analysis of the morphology of fibres and their derived indices are important factors in estimating pulp quality of any fibre material (Dinwoodie 1965). The morphology of the fibre and its derived indices correlates with most of the strength properties of pulp. Long softwood fibres are used to give essential strength while short hardwood fibres are used in furnishes to provide good printability and stiffness to end product. A fibre with thinner cell-walls will collapse more easily than a fibre with thicker cell-walls. Collapsed fibres are more 
flexible and have a higher area available for bonding. Collapsed fibres create a network with much higher density and lower bulk. Thus, paper will have a higher tensile strength, compression strength, burst strength, tensile stiffness and elasticity. The flexibility of the fibres has a large influence on the tensile strength, density, porosity and light scattering of the paper. Fibre cell lumen size and cell wall thickness affect the rigidity and strength properties of the papers (Panshin and de Zeeuw 1980). Fibres with large lumen and thin walls tend to flatten to ribbons during papermaking with enhanced inter-fibre bonding between fibres, and consequently having good strength characteristics (Oluwadare 1998, Osadare 2001). Generally, papers from hardwood pulps are lower in strength because of their shorter fibres than those of softwoods with longer fibres. Since the fibre properties vary greatly with species, the need to investigate the fibre properties of these hardwood is essential.

All processing conditions remaining the same, due to differences in wood types, properties of a piece of paper from different species will vary significantly. In this study, the fibre lengths of ten hardwood species were analysed to determine if they could be blended with long softwood fibre for pulp and paper making. Few reports are available in literatures on the fibre morphology of the studied species. Therefore, the objective of this study was to generate data on these species and define their suitability for pulp and paper making based on their fibre and derived morphological indices. These values were then compared to conventional raw materials for pulp and paper making.

\section{MATERIALS AND METHODS}

\section{Materials}

Ten different wood species were collected from Sawmills in Ilorin (Kwara state) and Mokwa (Niger State). These places fall within Guinea savannah regions of Nigeria. The wood Samples were first identified by the saw millers. The local identifications were further substantiated by the literature to obtain their corresponding scientific names. A list of the species used in the study with their local names is provided in Table 1. Wood samples were collected from logs whose diameter ranged from 60 - 105 centimetres. All of the wood samples were taken from mature wood. Special care was taken to ensure that species were accurately identified using both macroscopic and microscopic anatomical features such as colour, density, pores, among other.

Table 1: Wood samples used; their botanical name, family and local names.

\begin{tabular}{lll} 
Specie & Family & Local Names \\
\hline Lannea welwitchii Engl. & Anacardiaceae & Opon \\
Vitellaria paradoxa C.F. Gaertn. & Sapotaceae & Emi (Shea butter) \\
Afzelia africana Smith ex Pers & Caesalpinaceae & Apadan, Apa \\
Albizia zygia (DC.) Macb & Fabaceae & Ayunre \\
Anogeissus leiocarpus (DC) Guill. \& Perr. & Combretaceae & Ayin \\
Irvingia gabonensis Baill. ex Lanen & Irvingiaceae & Oro, African Bush Mango, \\
Khaya senegalensis A. Chev. & Meliaceae & Mahogany (Dry zone) \\
Vernonia colorata (Willd.) Drake & Compositea & Eriri \\
Isoberlinia doka Craib \& Stapf & Caesalpinaceae & Babo \\
Syzygium guineense (Willd.) DC. & Myrtaceae & Adere
\end{tabular}

\section{Fibre characterisation of the wood species}

Fibre characterisation of the wood samples was carried out following ASTM D-1030-95 (2007) and ASTM D-1413-61 (2007). Small slivers having radial and tangential dimensions of 2 and $5 \mathrm{~mm}$ from each of the wood species were macerated with acetic acid and hydrogen peroxide (1:1) and boiled in a water 
bath at a temperature of $100^{\circ} \mathrm{C}$ for 10 minutes following a procedure adopted by Ogbonnaya et al. (1997). Some macerated fibres were randomly selected and mounted on slides and then examined under a Reichet Microscope. The fibre length, fibre diameter and lumen width of unbroken fibres were measured using an eye piece micrometer after calibrating with stage micrometer. Some derived values such as the cell wall thickness (Fibre diameter - Lumen width/2); Slenderness Ratio (Fibre length/Fibre diameter); Flexibility coefficient (Lumen diameter/Fibre diameter); Runkel ratio ( 2 x Cell wall thickness/Lumen diameter), Rigidity coefficient ( 2 x Cell wall thickness/Fibre diameter), Luce's Shape Factor (Fibre diameter 2 - Lumen diameter 2 /Fibre diameter $2+$ Lumen diameter 2 ) and Solid Factor (Fibre diameter 2 - Lumen diameter 2 x Fibre length) were computed from the measured fibre dimensions following the method of Saikia et al. (1997), Ogbonnaya et al. (1997), Ohshima et al. (2005) and Sadiku et al. (2016). Twenty five fibres were measured from each representative sample slide.

\section{Statistical analysis}

Variation in the fibre morphology and derived values were evaluated by analysis of variance at $p \leq 0,05$. Duncan Multiple Range Test was used to compare mean values for the different species. The evaluated fibre morphology and derived values were compared to conventional species and some other hardwood species used in pulp and paper making.

\section{RESULT AND DISCUSSION}

\section{Fibre morphological variations of Species}

Fibre length and width of both woody and non-woody species vary depending on plant species and the plant part from which the fibre is derived (Illvessalo-Pfaffli 1995). The fibre morphological variations of the Nigerian guinea savannah timber species are presented in Table 2 and 3 . The analysis of variance shows that there were significant differences in the fibre length, fibre diameter, lumen width and the cell wall thickness of the timber species (Table 2). However, S. guineense had the longest fibre $(2 \mathrm{~mm})$ while A. zygia had the shortest fibre length of 1,05 mm. I. gabonensis had the largest fibre diameter, lumen width and cell-wall thickness. Least fibre diameter $(19,11 \mathrm{~m} \mu)$ and cell-wall thickness $(4,40 \mathrm{~m} \mu)$ were recorded in $V$. colorata (Table 3). S. guineense may be regarded as long fibred hardwood species with its average fibre length of $2 \mathrm{~mm}$ which falls in the range $(2-5 \mathrm{~mm})$ of long fibre material (Hurter 1988) while the remaining nine species are short fibred hardwood. However, Metcalfe and Chalk (1983) and Anon (1984) classified fibres below 1,60mm as short while those above $1,60 \mathrm{~mm}$ in length are said to be long. Going by this classification $S$. guineese, I. gabonensis and A. leiocarpa have long fibres while the other 7 species have short fibre lengths since their mean fibre lengths are all less than $1,60 \mathrm{~mm}$ (or $1600 \mu \mathrm{m}$ ) as presented in Table 3. This finding is in support of earlier reports and observations that the average length of fibres in hardwoods was only about $1 \mathrm{~mm}$ and in coniferous wood, about 3mm (Hurter 2001). Similarly observations, Kpikpi (1992) and Uju and Ugowoke (1997) reported fibre lengths of less than $1,60 \mathrm{~mm}$ in some Nigerian hardwood species.

Table 2: Analysis of variance for fibre dimension of the Nigerian guinea savannah wood species.

\begin{tabular}{llll}
\hline Fibre Morphology & df & MS & F-values \\
\hline Fibre Length $(\mathrm{mm})$ & 9 & 0,294 & $2,955^{* *}$ \\
Fibre Diameter $(\mu \mathrm{m})$ & 9 & 69,850 & $124,647 * *$ \\
Lumen Width $(\mu \mathrm{m})$ & 9 & 37,459 & $80,308^{* *}$ \\
Cell-wall thickness $(\mu \mathrm{m})$ & 9 & 0,730 & $42,366^{* *}$ \\
\hline
\end{tabular}

$* *=$ highly significant at $\mathrm{p} \leq 0,005$. 
Table 3: Variation in the fibre morphology of the Nigerian guinea savannah wood species.

\begin{tabular}{lllll} 
Species & $\begin{array}{l}\text { Fibre Length } \\
(\mathbf{m m})\end{array}$ & $\begin{array}{l}\text { Fibre Diameter } \\
(\boldsymbol{\mu m})\end{array}$ & $\begin{array}{l}\text { Lumen Width } \\
(\boldsymbol{\mu m})\end{array}$ & $\begin{array}{l}\text { Cell-wall } \\
\text { thickness }(\boldsymbol{\mu m})\end{array}$ \\
\hline L. welwitchii & $1,20^{\mathrm{bc}}$ & $24,00^{\mathrm{c}}$ & $12,65^{\mathrm{c}}$ & $5,68^{\mathrm{cde}}$ \\
V. paradoxa & $1,57^{\mathrm{abc}}$ & $21,14^{\mathrm{d}}$ & $8,87^{\mathrm{e}}$ & $6,13^{\mathrm{b}}$ \\
A. africana & $1,36^{\mathrm{bc}}$ & $23,15^{\mathrm{c}}$ & $12,00^{\mathrm{c}}$ & $5,58^{\mathrm{de}}$ \\
A. zygia & $1,05^{\mathrm{c}}$ & $23,96^{\mathrm{c}}$ & $12,03^{\mathrm{c}}$ & $5,97^{\mathrm{bc}}$ \\
A. leiocarpa & $1,75^{\mathrm{ab}}$ & $19,74^{\mathrm{e}}$ & $9,74 \mathrm{~d}^{\mathrm{e}}$ & $5,00^{\mathrm{f}}$ \\
I. gabonensis & $1,63^{\mathrm{abc}}$ & $33,75^{\mathrm{a}}$ & $19,80^{\mathrm{a}}$ & $6,87^{\mathrm{a}}$ \\
K. ivorensis & $1,12^{\mathrm{c}}$ & $22,76^{\mathrm{c}}$ & $12,03^{\mathrm{c}}$ & $5,37^{\mathrm{e}}$ \\
V. colorata & $1,52^{\mathrm{abc}}$ & $19,11^{\mathrm{e}}$ & $10,30^{\mathrm{d}}$ & $4,40^{\mathrm{g}}$ \\
I. doka & $1,13^{\mathrm{c}}$ & $23,05^{\mathrm{c}}$ & $11,56^{\mathrm{c}}$ & $5,75^{\mathrm{c}}$ \\
S. guineense & $2,00^{\mathrm{a}}$ & $31,86^{\mathrm{a}}$ & $18,18^{\mathrm{b}}$ & $6,84^{\mathrm{a}}$
\end{tabular}

Means in columns with the same superscript were not significantly different $(\mathrm{p} \leq 0,05)$.

For fine papers, both long and short fibres are needed. Short fibre contributes to the properties of pulp blends, especially opacity, printability and stiffness as well as good printability. Papers from these wood species, if blended with long fibre materials, will give good paper properties. However, the fibres from these species might not be flexible enough to allow the fibres to pack and reinforce the sheets. In the same vein, lumen size and cell wall thickness affect the rigidity and strength of the papers made from the fibres. Fibres with large lumen and thin walls tend to flatten to ribbons during pulping and papermaking, giving good contact between the fibres and consequently having good strength characteristics (Wood 1981). The fibres of the species are shorter, relatively thinner and flexible. The fibres will be able to pack tightly together and thus produce smooth and dense paper (Fengel and Wegener 1989, Mc Dougall et al. 1993).

The result of ANOVA showed that there was high significant variation in all the fibre dimensions (Table 2). S. guineense had the longest fibre length $(2 \mathrm{~mm})$ compared to other species followed by A. leiocarpa $(1,75$ $\mathrm{mm}$ ) while $A$. zygia had the shortest fibre length of $1,05 \mathrm{~mm}$ (Table 3). DMR test showed that $S$. guineense had extremely longer length than other species. There were no significant variation in the fibre length of $I$. doka, $K$. ivorensis and A. zygia. Also, V. colorata, I. gabonensis and V. paradoxa had similar fibre length. While $A$. africana and $L$. welwitchii had comparable fibre length (Table 3).

The fibre lengths of A. africana and L. welwitchii were similar. L. welwitchii and A. africana, A. zygia, K. ivorensis and I. doka had similar fibre diameter and lumen width. The cell-wall were thickest in I. gabonensis $(6,87 \mu \mathrm{m})$ and $S$. guineense $(6,84 \mu \mathrm{m})$ and thinnest in $K$. ivorensis $(5,37 \mu \mathrm{m})$ (Table 3$)$. It is expected that the properties of paper will greatly differ among the wood species under study. Therefore, the species which show no significant variation in their fibre length are expected to behave in similar way when they are pulped for paper making. In all, $S$. guineese is expected to produce better paper properties due to its exceptional fibre length compared to other species. Paper manufactured from thick walled fibres will be dense and possess coarse surface whereas paper made from thin walled fibre will be dense and well formed (Akachukwu 2001).

\section{Derived morphological indices}

Similarly to the fibre morphology, all the derived morphological indices showed high significant variations from species to species (Table 4). The derived values obtained for the wood species in this study is shown in Table 5. The most important and primary parameter needed to find the suitability of any raw material for pulp and paper is the Runkel ratio. The standard for this ratio is one (1), favourable pulp strength properties are usually obtained when value is below the standard value. I. gabonensis $(0,7)$ and $S$. guineense $(0,75)$ had the best RR while $V$. paradoxa and $A$. leiocarpa had poor RR. All the species exhibited good slenderness ratio with moderate rigidity while I. gabonensis and V. paradoxa had the best felting power. 
Table 4: Analysis of variance for derived values of the wood species.

\begin{tabular}{llll}
\hline Derived Values & df & MS & F-values \\
\hline Runkel ratio (RR) & 9 & 0,106 & $24,452^{* *}$ \\
Flexibility coefficient (FC) & 9 & 0,006 & $24,093 * *$ \\
Slenderness ratio (SR) & 9 & 0,001 & $3,497 * *$ \\
Luce's shape factor (LSF) & 9 & 0,010 & $23,936 * *$ \\
Solid factor (SF) & 9 & 365235,431 & $27,065^{* *}$ \\
Rigidity Coefficient (RC) & 9 & 0,007 & $22,140 * *$ \\
\hline
\end{tabular}

Table 5: Variation in the derived morphological indices of the wood species.

\begin{tabular}{|c|c|c|c|c|}
\hline Species & $\mathbf{R R}$ & FC & SR & RC \\
\hline L. welwitchii & $0,90^{\mathrm{cd}}$ & $53^{b c}$ & $50,00^{\mathrm{cd}}$ & $0,47^{\mathrm{cd}}$ \\
\hline$V \cdot$ paradoxa & $1,38^{a}$ & $42^{\mathrm{e}}$ & $70,00^{\mathrm{abc}}$ & $0,58^{\mathrm{a}}$ \\
\hline A. africana & $0,93 b^{c d}$ & $52^{\text {bcd }}$ & $60,00^{\mathrm{bcd}}$ & $0,48^{\text {bcd }}$ \\
\hline A. zygia & $0,99^{\mathrm{bc}}$ & $50^{\mathrm{cd}}$ & $40,00^{d}$ & $0,50^{\mathrm{bc}}$ \\
\hline A. leiocarpa & $1,03^{b}$ & $49^{d}$ & $90,00^{a}$ & $0,51^{\mathrm{b}}$ \\
\hline I. gabonensis & $0,70^{\mathrm{f}}$ & $59^{\mathrm{a}}$ & $50,00^{\mathrm{cd}}$ & $0,41^{\mathrm{e}}$ \\
\hline K. ivorensis & $0,90^{\mathrm{cd}}$ & $53^{b c}$ & $50,00^{\mathrm{cd}}$ & $0,47^{\mathrm{cd}}$ \\
\hline V. colorata & $0,86^{\text {de }}$ & $54^{b}$ & $80,00^{a b}$ & $0,46^{d}$ \\
\hline I. doka & $1,00^{b c}$ & $50^{\mathrm{cd}}$ & $50,00^{\mathrm{cd}}$ & $0,50^{b c}$ \\
\hline S. guineense & $0,75^{\text {ef }}$ & $57^{\mathrm{a}}$ & $60,00^{\mathrm{abcd}}$ & $0,43^{\mathrm{e}}$ \\
\hline
\end{tabular}

Means in columns with the same superscript were not significantly different $(\mathrm{p} \leq 0,05)$ Slenderness Ratio (SR); Flexibility coefficient (FC); Rigidity coefficient (RC); Runkel Ratio (RR).

The flexibility coefficient which is otherwise known as elasticity coefficient, or Istas coefficient, is a function of the elasticity of the wood fibres. Depending on the elasticity rate, fibres are grouped into four following Istas et al. (1954) and Bektas et al. (1999) grouping (Table 7).

Table 6: Elasticity coefficients of the wood fibres.

\begin{tabular}{lc} 
Type of Fibres & Elasticity Coefficient \\
\hline High Elastic fibres & $>75$ \\
Elastic fibres & $50-75$ \\
Rigid fibres & $30-50$ \\
High Rigid fibres & $<30$
\end{tabular}

Istas et al. (1954) and Bektas et al. (1999). 
According to this grouping, $V$. paradoxa and A. leiocarpa are included in the rigid fibres group owing to their elastic coefficient less than 50 while the other 8 wood species have their elasticity coefficient $\geq 50$ and are therefore included in the elastic fibre group (Table 6). Rigid fibres do not have efficient elasticity, so they are not suitable for paper production and are used more for cardboard production and (Akgül and Tozluoğlu 2009).

The results of the ANOVA showed that there was high significant variation in all the derived values (Table 4) while the DMR test (Table 5) revealed that $L$. welwitchii, A. africana, K. ivorensis had similar RR while $A$. zygia and $I$. doka also had similar runkel ratio, fibre flexibility and rigidity. FC, SR and RC of $L$. welwitchii and K. ivorensis were similar. I. gabonensis and S. guineense had the most flexible fibres (Table 7). A. leiocarpa had the most slender fibre. V. paradoxa fibres are the most rigid (Table 7).

Table 7: Fibre flexibility classification of the wood species.

\begin{tabular}{lcc}
\hline Species & Elasticity Coefficient (FC) & Type of fibre \\
\hline L. welwitchii & 53 & Elastic \\
V. paradoxa & 42 & Rigid \\
A. africana & 52 & Elastic \\
A. zygia & 50 & Elastic \\
A. leiocarpa & 49 & Rigid \\
I. gabonensis & 59 & Elastic \\
K. ivorensis & 53 & Elastic \\
V. colorata & 54 & Elastic \\
I. doka & 50 & Elastic \\
S. guineense & 57 & Elastic \\
\hline
\end{tabular}

The suitability of the wood species for pulp and paper-making is shown in Table 8 . The range of RR reported for the wood species falls in the range with 0,99 reported for both Anthonatha macrophylia and Dalium guinensis (Ezeibekwe et al. 2009) and 0,75 reported by Awaku (1994) for some tropical hardwood species but higher than 0,28 - 0,68 reported for Gmelina arborea and some Ficus species respectively (Ogunkunle 2010), 059 for Leucaena leucocephala (Oluwadare and Sotannde 2007), and 0,70 for Dacryodes edulis (Ajuziogu et al. 2010). From the findings, all the species had $\mathrm{RR} \leq 1$ except $V$. paradoxa and $A$. leiocarpa which do not pass the $\mathrm{RR}<1$ acceptable value for papermaking fibre (Xu et al. 2006) (Table 8). This implies that V. paradoxa and A. leiocarpa are not suitable for pulping considering their runkel ratio as they are relative higher than other wood species. Their RR falls into the range of undesirable runkel ratio. This makes the fibres from these wood not good enough as quality raw material for quality pulp and paper. Dinwoodie (1965) stated that, the basis for establishing the suitability of raw material for pulp and paper making is that the Runkel ratio must be less than one. If the Runkel ratio is less than one, such fibre source is suitable for paper production (Volkomer 1969). In the same vain, Bektas et al. (1999) stated that higher Runkel ratio gives lower paper strength properties especially lower burst, tear and tensile indexes. Fibre with high runkel ratio value is stiff, less flexible and form bulkier paper of low bounded area than the lower ratio fibre. Therefore, it is expected that V. paradoxa and $A$. leiocarpa will produce poor paper. 
Table 8: Suitability for pulp and paper-making based on fibre length and runkel ratio.

\begin{tabular}{lclcc}
\hline Species & Fibre length & Fibre Class & Runkel Ratio & Ranking \\
\hline Lannea welwitchii & 1,20 & Short & 0,90 & Good \\
Vitellaria paradoxa & 1,57 & Medium long & 1,38 & Poor \\
Afzelia africana & 1,36 & Short & 0,93 & Good \\
Albizia zygia & 1,05 & short & 0,99 & Good \\
Anogeissus leiocarpus & 1,75 & Medium long & 1,03 & Poor \\
Irvingia gabonensis & 1,63 & Medium long & 0,70 & Good \\
Khaya senegalensis & 1,12 & Short & 0,90 & Good \\
Vernonia colorata & 1,52 & Medium long & 0,86 & Good \\
Isoberlinia doka & 1,13 & Short & 1,00 & Good \\
Syzygium guineense & 2,00 & Long & 0,75 & Good \\
\hline
\end{tabular}

The degree of fibre bonding depends largely on flexibility and compressibility of individual fibre. Other calculated wood properties of importance are flexibility ratio and rigidity coefficient. Flexibility ratio is another important criterion for evaluating fibre quality. High flexibility shows that a material may be suitable to produce paper with greater burst and tensile strength. The higher the value of fibre length to width ratio, the greater will be the fibre flexibility and the chance of forming well bonded paper. Similarly, an increase in the rigidity of fibres results in decrease in fibre bonding. The flexibility of all the wood species are in the range of 42 and 59 with I. gabonensis having the highest (59\%) followed by S. guineese (57\%) (Table 7). This range is almost similar to (Brindha et al. 2012) where $60 \%$ was reported. Considering the FC $>0,55(55 \%)$ acceptable value for papermaking fibre (Bektas et al. 1999), two of the species I. gabonensis and S. guineese will be suitable. However, flexibility ratio between 50 and 70 implies that the fibers can easily be flat and give good paper with high strength properties (Brindha et al. 2012). Therefore, V. paradoxa and A. leiocarpa may not be suitable due to their low $\mathrm{FC}$ of $42 \%$ and $49 \%$ respectively.

It is expected that the pulp made from all the wood species except $V$. paradoxa and A. leiocarpa will have greater inter-fibre bond and hence greater tensile strength which favour those properties that affects printing (Ogunjobi et al. 2014). Fibre slenderness significantly influenced the breaking length, bursting, tearing and stretch of the pulp sheets (Ogunjobi et al. 2014). All the species pass the SR $>33$ acceptable value for papermaking fibre according to Xu et al. (2006). However, Bektas et al. (1999) shows that if Slenderness ratio is lower than 70, it is invaluable for quality pulp and paper production (Bektas et al. 1999). But, if the Slenderness ratio is higher than 70, it can be utilized for pulp and paper production. The felting power of the wood species under study is in the range of 40 - 90 with $P$. elata having the highest (59) felting power followed by $V$. colorata (57). These values are lower than 101,50 felting coefficient of Steculia setigera reported by Oluwadare and Egbewole (2008). There were no significant variation in the felting power of L. welwitchii, I. gabonensis, $K$. ivorensis, I. doka. While $A$. africana and $S$. guineese had similar slenderness ratio too. Only $A$. zygia do not fall in the range suitable for paper making owing to very low felting power of $40 \%$. Generally, resistance to tear increases with increasing fibre slenderness paper made from all the species is expected to have increased tear strength suitable for wrapping and packaging purposes (Sankia et al. 1997).

\section{CONCLUSIONS}

The wood species fibre falls into short $(1,05$ - 1,36), medium long (1,52 - 1,75) and long (2,0 mm) fibres. $V$. paradoxa and A. leiocarpa fibres are rigid owing to their elastic coefficient less than 50 while the other eight (8) wood species have their elasticity coefficient $\geq 50$ and are therefore included in the elastic fibre group. All the wood species pass the Runkel Ratio $<1$ acceptable values for paper making fibre except $V$. paradoxa and A. leiocapa with RR value of 1,38 and 1,03. S. guineense and I. gabonensis pass FC $>0,55$ acceptable value for paper making. The rigidity of the fibres are low therefore will enhance fibre bonding. Pulp produced from these wood species can be mixed with soft-wood or recycled paper pulps to further improve their properties 


\section{REFERENCES}

Ajuziogu, G.C.; Nzekwe, U.; Chukwuma, H. I. 2010. Assessment of Suitability of Fibres of Four Nigerian Fruit Trees for Paper-Making. Bio-Research 8(2):679-681.

Akgül, M.; Tozluoğlu, A. 2009. Some Chemical and Morphological Properties of Juvenile Woods from Beech (Fagus orientalis L.) and Pine (Pinus nigra A.) Plantations. Trends in APPLIED Sciences Research 4(2): 116-125.

Akachukwu, A.E. 2001. Study of Reaction among some wood features in Hardwood species. Journal of Tropical Forest Resources 5:72-78.

American Society for Testing and Materials. ASTM. 2007. Preparation of decayed wood for microscopical examination, ASTM D-1413-61. West Conshohocken, PA.

American Society for Testing and Materials. ASTM. 2007. Standard test method for fiber analysis of paper and paperboard, ASTM D-1030-95. West Conshohocken, PA.

Anon. 1984. Chemical Analysis of Nigerian Grown timbers. Annual Report of the Forestry Research Institute of Nigeria. Jan. - Dec., p. 108-109.

Awaku, F.A. 1994. Anatomical Properties of Afina (Strombosia glaucescens, var Lucida J. Leonard). Ghana Journal of Forestry 1:30-33.

Bektas, I.; Tutus, A.; Eroglu, H. 1999. A study of the suitability of Calabrian Pine (Pinus burtia, Jen) for pulp and paper manufacture. Turk J Agri For 23(3):589-597.

Brindha, D.; Vinodhini, S.; Alarmelumangai, K. 2012. Fiber dimension and chemical contents of fiber from passiflora foetida, 1. And their suitability in paper production. Science Research Reporter 2(3): 210-219.

Dinwoodie, J.M. 1965. The relationship between fibre morphology and paper properties of: A Review of Literature. Tappi 48: 440-447.

Ezeibekwe, I.O.; Okeke, S.E.; Unamba, C.I.; Ohaeri, J.C. 2009. An Investigation into the potentials of Dactyladenia bacteri; Dialum guineense; and Anthonotama crophylia for Paper Pulp Production. Report and Opinion 1(4): 18-25. Berlin.

Fengel, D.; Wegener, G. 1989. Wood Chemistry, Ultrastructure, Reactions. $2^{\text {nd }}$ Edition, Walter de Gruyter:

Hurter, A.M. 1988. Utilization of annual plants and agricultural residues for the production of pulp and paper. In: Proceedings of TAPPI pulping conference. New Orleans, LA, USA, Book1. TAPPI Press: Atlanta, GA, p.139-160.

Hurter, R.W. 2001. Agricultural Fibers for Paper pulp. Outlook on Agriculture 8(3): 96-103. p.400.

Illvessalo-Pfaffli, M.S. 1995. Fibre atlas. Identification of Papermaking fibres. Springer - Verlag: Berlin,

Istas, J.R.; Heremans, R.; Roekelboom, E.L. 1954. Caracteres Generaux De Bois Feuillus Du Congo Belge En Relation Avec Leur Utilization Dans I 'industrie Des Pates A Paper: Etude Detaillee De Quelques Essences. Serie Technique, No. 43. Gembloux: INEAC.

Jaiyeola, A.A.; Aworinde, D.O.; Folorunso, A.E. 2009. Use of wood characters in the identification of selected timber species in Nigeria. Notul. Bot. Horti Agrobot. Cluj-Napoca Inst. Agron "Dr. Petru Groza" 37(2): 28-32.

Kpikpi, W.M. 1992. Wood structure and paper-making potentials of Ricinodendron heudelotti and Albizia zygia in relation to Gmelina arborea. Niger J Bot 5: 41-50. 
Kpikpi, W.M.; Olatunji, A.O. 1990. Wood Anatomy Consideration in Deciding the Suitability of Some Nigerian Hardwoods for Pulp and Paper Production. Nigerian J Bot 3: 137 - 150.

Mcdougall, G.J.; Morrison, I.M.; Stewart, D.; Weyers, J.D.B.; Hillman, J.R. 1993. Plant fibers -botany, chemistry and processing for industrial use. J Sci Food Agric 62: 1-20.

Metcalfe, C.R.; Chalk, L. 1983. Anatomy of the dicotyledons 2, 2. Nordic Journal of Botany 4(5): 668668.

Ogbonnaya, C.I.; Roy-Macauley, H.; Nwalozie M.C.; Annerose, D.J.M. 1997. Physical and histochemical properties of Kenaf (Hibiscus cannabinus L.) grown under water deficit on a sandy soil. Industrial Crops Product 7: 9-18.

Ogunkunle A.T.J. 2010. A Quantitative Modelling of Pulp and Paper Making Suitability of Nigerian Wood Species. Advances in Natural and Applied Sciences 4(1): 14-21.

Ogunkunle A.T.J.; Oladele, F.A. 2008. Structural Dimensions and Paper Making Potentials of the Wood in Some Nigerian Species of Ficus L. (Moraceae). Advances in Natural and Applied Sciences 2(3): 103-111.

Ogunjobi, K.M.; Adetogun A.C.; Omole A. O. 2014. Assessment of Variation in the Fibre Characteristics of the Wood of Vitex Doniana Sweet and its Suitability for Paper Production. Journal of Research in Forestry Wildife and Environmental 6(1):39 - 51.

Ogunwusi, A.A. 2002. Wood properties of Sterculia setigera forming in the savanna belt of Nigeria. Niger J For 32(1): 50-55.

Ohshima, J.; Yokota, S.; Yoshizawa, N.; Ona, T. 2005. Examination of within-tree variations and the heights representing whole-tree values of derived wood properties for quasi-non-destructive breeding of Eucalyptus camaldulensis and Eucalyptus globulus as quality pulpwood. J Wood Sci 51(2):102-111.

Oluwadare, A.O. 1998. Evaluation of the Fibre and Chemical Properties of Some Selected Nigerian Wood and No-wood species for pulp production. J Trop For Res 14: 110-119.

Oluwadare, A.O.; Sotannde, O.A. 2007. The Relationship Between Fibre Characteristics and Pulpsheet Properties of Leucaena leucocephala (Lam.) De Wit. Middle-East. Journal of Scientific Research 2(2): 63-68.

Oluwadare, A.O.; Egbewole, Z.T. 2008. Wood Quality Studies in Plantation Grown Steculia (Steculia setigera) in the Guinea Savannah, Nigeria. Research Journal of Forestry 2: 22-33.

Osadare, A.O. 2001. Basic wood and pulp properties of Nigerian-grown Caribbean pine (Pinus caribaea Morelet) and their relationship with tree growth indices. Ph.D. thesis University of Ibadan. 347Pp.

Osadare, O.A. 1997. Strategies for long fibre pulp production in Nigeria. Niger J For 24(1-2): 16-20.

Panshin, J.; de Zeeuw, C. 1980. Textbook of wood technology. 4th edition Mc Grawhill: New York, p: 772.

Sadiku, N.A.; Oluyege, A.O.; Ajayi, B. 2016. Fibre dimension and chemical characterisation of naturally grown Bambusa vulgaris for pulp and paper production. J Bamboo and Rattan 15(1-4): 33-43.

Saikia, S.N., Goswami, T.; Ali, F. 1997. Evaluation of pulp and paper making characteristics of certain fast growing plants. Wood Science and Technology 31(6): 467-475.

Sankia, D.G.; Gaswani, T.; Sankia, C.N. 1997. Wild Banana as a Source of Fibre for Paper and Cordage Industries. J Sci Ind Res 54: 408-413.

Uju, C.C.; Ugwoke, C.E. 1997. Studies on the dimensions and suitability of wood fibres of selected tree species of the family Moraceae in papermaking. Nigerian Journal of Botany 10: 7-13. 
Volkomer, P.J. 1969. Wood Raw Materials for Pulp and Paper in Tropical Countries. FAO International Review of Forestry and Forest Products. Unasylva 23(3).

Wood, I.M. 1981. The utilization of field crops and crop residues for paper pulp production. Field Crop Abstracts 34: 557-568.

Xu, C. Y.; Wang, H.X.; Zhang, X.Y.; Fu, S.Y.; Wu, J.E. 2006. Lignocellulose Selectivity Degradation of White Rot Fungi in Bamboo. J Microbiol 26: 14-18. 